\title{
THE ANT, MONOMORIUM CARBONARIUM EBENINUM FO- REL, IN A NEW ROLE: AS PREDATOR ON THE EGG- CLUSTERS OF DIATRAEA SACCHARALIS F. IN PUERTO RICAN CANE FIELDS
}

\author{
$\mathrm{By}$ \\ Groras N. Woucorr, Entomologist, \\ and \\ LuIs Fr. MarronetL, Assistant Entomologist,
}

One-sixth of the nearly 9,000 egg-clusters of the sugar-cane mothborer, Diatraea saccharalis F., collected between September 1936 and September 1937 in the cane fields of Puerto Rico, had been partly or completely devoured by some predaceous animal at the time of observation. The mere presence of a moth-borer egg-mass on the cane leaf often causes the eventual appearance of a chlorotic spot in the leaf tissue, and many such chlorotic spots shaped like egg-clusters were noted but could not be included in the count because no bit of eggshell remained to prove definitely that an egg-mass had previously rested there. Sometimes the predaceous animal had left the merest rim of chorion; more often the entire lower layer of the egg-shell remained attached to the leaf. Sometimes only part of the eggcluster had been eaten, and under these circumstances it was possible to note that it apparently made little difference to the animal feeding upon them whether the eggs were fresh and unparasitized, or whether they were black from the attack of Trichogramma minutum Riley. Egg-masses from which the caterpillars had hatched, and those from which the parasites had emerged were also often eaten, but rarely consumed so completely and neatly: in many cases they were merely bitten into and messed up.

The observations on the presence of moth-borer egg-clusters were made during each month of the year in every important cane-producing section of the Island. Listing every eaten egg-cluster by localities indicates little difference in geographic distribution. To be sure, the Ponce region with 150 eaten egg-clusters, the Guayama-Yauco region with an equal number and the Guánica-Yanco region with 123, seems to indicate a somewhat greater abundance in the semi-xerophytic South Coast than 120 in the Toa Baja-Dorado region and 107 in 
the Arecibo region, but the total of all North Coast observations is more than for the South Coast. Noting all the instances where more than half of all the egg-clusters observed in the field had been eaten indicates quite a chance distribution, as do also the few instances where all egg-clusters had been eaten. The greatest number of eaten egg-clusters collected in an hour was at Toa Baja on February 23, 1937, where, out of a total of 70 , those eaten numbered 30 .

The differences in the completeness and neatness with which eggclusters were eaten suggested that more than one kind of organism might be responsible. The Coccinellid beetle, Cycloneda sanguinea L., is a common insect in cane fields, being an important predator on the yellow aphis, Sipha flava Forbes. Presumably it could eat other bits of animal matter of equivalent size, but it has never been observed in the field feeding on moth-borer eggs, and when confined with them in a cage, did not eat them. The beautiful red and blue Lycid beetle, Thonalmus chevrolati Bourgeois, of which nothing is specifically known as to its food-habits (altho they are supposed to be predaceous), is common in fields of young cane in the Guánica region, but, tested in a cage experiment, also gave negative results.

In a field of young ratoon cane near Río Piedras, examined on October 1, 1936 by the junior writer, small black ants were noted feeding on a partly parasitized egg-cluster. Specimens submitted to Dr. M. R. Smith were identified by him as Monomorium carbonarium F. Smith, subsp. ebeninum Forel. Ants of this species (as determined by the writers) were repeatedly noted subsequently feeding on egg-clusters altho the field notes record only the following: at Isabela on December 23, 1936 eating fresh eggs; at Toa Baja, May 4th, 1937, eating parasitized eggs; at Quebradillas on July 15th, also eating parasitized eggs; and at Yabucoa on July 29th, eating the egg-shells of a hatched cluster. It is possible that some other predator may be responsible for some of the eaten egg-clusters, but at this minute black ant is the only organism which has been actually seen in the field eating the eggs, and as the records show that it feeds on fresh, parasitized and hatched eggs, it would appear probable that it is responsible for most, if not all of the destruction noted. Monomorium carbonarium ebeninum is a common ant in all parts of Puerto Rico, living in various places besides cane fields. In canc fields, its previously recorded activities were to nest under the leaf- 
sheaths of cane and in moth-borer tunnels in the stalks of cane, and to attend the yellow aphis, Sipha flava Forbes. It has not previously been observed feeding on the egg-masses of Diatraea saccharalis F., yet the number of them eaten in Puerto Rico is so large that, were this ant more discriminating in its choice of the character of the eggs (whether fresh, parasitized or merely shells) on which it feeds, it would be a factor of importance in the natural control of the moth-borer of sugar-cane. In the fields, or at the times when the wasp parasite, Trichogramma minutum Riley, is searce or absent, however, this ant appears to be the only natural agent tending to reduce their numbers, and, under these conditions and in this phase of its activities, is unquestionably beneficial to the interests of the cane-grower. 